ENDOCRINOLOGY

FIRST SESSION

May $17,1973,1: 30$ P.M.

California Room

MODERATOR: Delbert A. Fisher

1. 1:30 Lawson Wilkins Lecture Hereditary Metabolic Defects Causing Pseudohermaphroditism. Andrea Prader, Zurich.

2. 2:30 FSH: ITS MEDIATING ROLE ON TESTOSTERONE SECRETION IN HYPOPITUITARISM. Raphael Rappaport, Pierre C. Sizonenko, Nathal ie Josso and Fernand Dray. (Intr. by Donough O'Brien). Descartes Univ. Med. Sch., Hopital des Enfants Malades, Paris, France, and Univ. of Geneva Med. Sch., Dept. of Ped., Geneva, Switerzerland.

3. $2: 45$ AUTONOMOUS MATURATION OF THE BRAIN HYPOTHALAMIC PITUITARY GONADOTROPHIN SYSTEM. Jordan W. Finkelstein, Robert M. Boyar, Howard P. Roffwarg, Leon Hellman, Albert Einstein Col. of Med., Montefiore Hosp. E Med. Ctr., Inst. for Steroid Res., Dept. of Ped., Dept. of Oncology, Dept. of Psychiatry, Bronx, New York.

4. 3:00 ONTOGENY OF POSITIVE FEEDBACK: LUTEINIZING HORMONE (LH) RELEASE IN PRE- AND POSTPUBERTAL GIRLS FOLLOWING EXOGENOUS ADMINISTRATION.

H. E. Kulin and E. O. Reiter, NIH, Bethesda.

5. 3:15 INTERFERENCE WITH THE ONSET OF PUBERTY AND REPRODUCTIVE FUNCTION IN FEMALE RAT BY PRE- AND/OR POST NATAL CYANOKETONE (CTM), ANTI-BODIES TO LH: FSH, AND ACTINOMYCIN-D. Allen S. Goldman and Bernard H. Shapiro, Childrens Hosp. of Philadelphia, Philadelphia.

- $3: 30$ Intermission -

6. 3:35 ENDOCRINE EFFECTS OF BRAIN SEROTONIN (5-HT) DEPLETION BY 5, 6DIHYDROXYTHRYPTAMINE (5,6-DHT) IN PREPUBERAL. MALE RATS. R. Collu, J. C. Jequier, J. Letarte, G. Leboeuf and J. R. Ducharme. Dept. of Ped., Ste-Justine Hsop., Univ. of Montreal, Montreal. 
7. 3:50 IMMUNOREACTIVE SERUM PARATHYROID HORMONE (IRPTH) ASSAY IN THE NEWBORN. David M. Brown \& Arnold W. Lindall. Dept. Ped. \& Lab. Med., Univ. of Minn. Minneapolis.

8. 4:05 FUNCTIONAL NEONATAL HYPOPARATHYROIDISM: ROLE OF GESTATIONAL AND POSTNATAL AGE. Reginald C. Tsang, I-wen Chen, Jean J. Steichen, Herbert Koffler, Lawrence W. Fenton, and Irwin J. Light, Univ. of Cinti, Col. of Med., Dept. of Ped., Cincinnati.

9. 4:20 A CLASSIFICATION OF THE HYPOPARATHYROID SYNDROME BASED ON THE PTH RESPONSE TEST. H. Peter Kind, David K. Parkinson, Se Mo Suh, Donald Fraser, Sang Whay Kooh. Dept. of Paed., Univ. of Toronto, and Research Institute, Hospital for Sick Children, Toronto.

10. $4: 35$ INDUCTION OF TESTICULAR CYCLIC NUCLEOTIDE PHOSPHODIESTERASE BY ICSH AND FSH. Robert 0 . Charistiansen and Marcia Desautel. Stanford University School of Medicine Dept. of Peds., Stanford, California.

11. 4:50 ENDOCRINE RESPONSES IN ANENCEPHALY. Joseph B. Warshaw and Alberto Hayek Harvard Med., Sch., Mass. Gen. Hosp., Shriners Burns Inst. Boston. 


\section{ENDOCRI NOLOGY}

\section{SECOND SESSION}

May 19, 1973, 2:00 P.M.

\section{California Room}

12. 2:00 SOMATOMEDIN ACTIVITY IN PLASMA OF CHILDREN RECEIVING PREDNISONE. M. J. Elders, B.S. Wingfield, L. M. McNatt and E. R. Hughes, Depts. of Ped. Univ. of Arkansas Med. Cntr., Little Rock and Univ. of W.Va., Morgantown.

13. 2:15 RELATIONSHIPS BETWEEN PLACENTAL CONCENTRATIONS OF CHORIONIC SOMATOMAMMOTROPIN AND TWIN GROWTH. Duncan R. MacMillan, Anne M. Brown, Adam P. Matheny, and Ronald S. Wilson. Univ. of Louisville Sch. of Med., Louisville. (Introduced by Jacquel ine Noonan)

14. 2:30 RESTORATION OF GROWTH BY HUMAN GROWTH HORMONE (ROOS) IN HYPOPITUITARY DWARFS WITH ANTIBODIES INDUCED BY hGH (U.S.). Louis E. Underwood, Sandra J. Voina, Judson J. Van Wyk, Univ. of North Carolina Sch. of Med., Dept. of Ped., Chapel Hill.

15. 2:45 THE MECHANISM OF FETAL TRIIODOTHYRONINE (T3) DEFICIENCY. Joseph Sack, Allen Erenberg, William Oh and Delbert A. Fisher, Harbor General Hosp., Dept. of Pediatrics, Torrance, Calif.

16. 3:00 INAPPROPRIATE TSH SECRETION IN A CHILD WITH T 3 THYROTOXICOSIS. Margaret MacGillivray, D.A. Fisher, G.C. Schussler, 'J. R. Warner. Depts. Ped. \& Med. SUNY at Buffalo, N.Y. \& UCLA, Torrance, Cal.

\section{- $3: 15$ Intermission -}

17. $3: 30$ ADENYLATE CYCLASE (AC) RESPONSE TO CLUCAGON OF FETAL LIVER PLASMA MEMBRANES. Solomon A. Kaplan and Barbara M. Lippe, Dept. of Ped., UCLA Sch. Med., Los Angeles.

18. $3: 45$ INSULIN AND PROINSULIN SECRETION IN CHEMICAL AND OVERT JUVENILE DIABETICS. George A. Burghen, James N. Etteldorf, Robert L. Trouy, and Abbas E. Kitabchi. College of Med. Univ. of Tennessee, Depts. of Pediatrics and Medicine, Memphis. 
19. 4:00 NATURAL HISTORY OF CHEMICAL DIABETES IN CHILDHOOD AND INTERVENTION WITH SULFONYLUREA THERAPY. Elsa P. Paulsen, Ped. Dept., University of Virginia Med Center, Charlottesville.

20. 4:15 MALE PSEUDOHERMAPHRODITISM DUE TO 17 \& HYDROXYLASE DEFICIENCY IN TWO SIBLINGS. Marcos N. Alvarez, Mark D. Cloutier, and Alvin B. Hyales. Mayo $\mathrm{Clinic}$ and Foundation, Department of Pediatrics, Rochester, Minn.

21. $4: 30$ MULTIPLE MUCOSAL NEUROMATA WITH MEDULLARY CARCINOMA OF THE THYROID R. S. Brown, E. Colle, and A. H. Tashjian, Jr., Montreal Children's Hosp. McGill Univ. Research Institute, Montreal, and Dept. of Pharmacology, Harvard School of Dental Medicine, and Harvard Med. Sch., Boston. 